\title{
Aryl hydrocarbon receptor (AhR) agonists suppress interleukin-6 expression by bone marrow stromal cells: an immunotoxicology study
}

\author{
Brenda A Jensen, Rebecca J Leeman, Jennifer J Schlezinger and \\ David H Sherr*
}

Address: Department of Environmental Health, Boston University School of Public Health, 715 Albany Street, Boston, MA 02118, USA

Email: Brenda A Jensen - bjensEn@bu.edu; Rebecca J Leeman - rleeman@bu.edu; Jennifer J Schlezinger - jschlezi@bu.edu;

David H Sherr* - jschlezi@bu.edu

* Corresponding author

Published: 16 December 2003

Environmental Health: A Global Access Science Source 2003, 2:16

This article is available from: http://www.ehjournal.net/content/2/l/16

(c) 2003 Jensen et al; licensee BioMed Central Ltd. This is an Open Access article: verbatim copying and redistribution of this article are permitted in all media for any purpose, provided this notice is preserved along with the article's original URL.
Received: 01 October 2003

Accepted: 16 December 2003

\begin{abstract}
Background: Bone marrow stromal cells produce cytokines required for the normal growth and development of all eight hematopoietic cell lineages. Aberrant cytokine production by stromal cells contributes to blood cell dyscrasias. Consequently, factors that alter stromal cell cytokine production may significantly compromise the development of normal blood cells. We have shown that environmental chemicals, such as aromatic hydrocarbon receptor (AhR) agonists, suppress $B$ lymphopoiesis by modulating bone marrow stromal cell function. Here, we extend these studies to evaluate the potential for two prototypic AhR agonists, 7,12-dimethylbenz [a]anthracene (DMBA) and 2,3,7,8-tetrachlorodibenzo-p-dioxin (TCDD), to alter stromal cell cytokine responses.
\end{abstract}

Methods: Bone marrow stromal cells were treated with AhR agonists and bacterial lipopolysaccharide (LPS) to mimic innate inflammatory cytokine responses and to study the effects of AhR ligands on those responses. Steady state cytokine RNA levels were screened by RNAse protection assays (RPA) and quantified by real-time PCR. Cytokine (IL-6) protein production was measured by ELISA. NF-KB EMSAs were used to study IL-6 transcriptional regulation.

Results: RPAs indicated that $\mathrm{AhR}^{+}$bone marrow stromal cells consistently up-regulated genes encoding IL-6 and LIF in response to LPS, presumably through activation of Toll-like receptor 4. Pre-treatment with low doses of DMBA or TCDD selectively abrogated IL-6 gene induction but had no effect on LIF mRNA. Real-time-PCR indicated a significant inhibition of IL-6 mRNA by AhR ligands within I hour of LPS challenge which was reflected in a profound down-regulation of IL-6 protein induction, with DMBA and TCDD suppressing IL- 6 levels as much as $65 \%$ and $88 \%$, respectively. This potent inhibitory effect persisted for at least 72 hours. EMSAs measuring NF- $\mathrm{kB}$ binding to IL- 6 promoter sequences, an event known to induce IL- 6 transcription, indicated a significant decrease in the LPS-mediated induction of DNA-binding RelA/p50 and c-Rel/p50 heterodimers in the presence of DMBA.

Conclusions: Common environmental AhR agonists can suppress the response to bacterial lipopolysaccharide, a model for innate inflammatory responses, through down-regulation of IL-6, a cytokine critical to the growth of several hematopoietic cell subsets, including early $B$ cells. This suppression occurs at least at the level of IL-6 gene transcription and may be regulated by NF- $\mathrm{KB}$. 


\section{Background}

Bone marrow stromal cells support the growth and development of all eight hematopoietic cell lineages through cell-cell contact and the production of soluble cytokines $[1,2]$. Although this process generally is well-regulated by both adhesion molecules and receptor/ligand pairs, aberrant stromal cell-blood cell interactions have been documented and are associated with a variety of diseases that involve abnormal growth and development of blood cells [3-5].

Perhaps the best studied stromal cell-blood cell interaction is that which occurs between bone marrow stroma and developing B lymphocytes [6-9]. Of particular interest in these studies is the contribution of stromal cell-derived IL-6 to B lymphopoiesis. Originally described as a tumorderived growth factor [10], IL-6 now is known to be required for the growth of normal bone marrow progenitor B cells [11], for terminal differentiation of surface immunoglobulin-bearing $B$ cells $[12,13]$, and for the long-term survival of bone marrow plasma cells [13-15].

Aberrant IL-6 expression has been associated with autoimmune diseases, including, but not limited to vitiligo [16], systemic lupus erythematosus (SLE) $[17,18]$, rheumatoid arthritis [19], and multiple sclerosis [20]. Moreover, IL-6 has been recognized as an important growth and survival factor for neoplastic bone marrow plasma cells in multiple myeloma $[5,14,21]$ and has been targeted with specific antibodies for myeloma therapy [22]. In addition, IL-6 is emerging as an important survival and angiogenesis factor in other cancers, including basal cell carcinoma, prostate cancer, and Kaposi's carcinoma [23-25]. These studies illustrate the importance of IL- 6 regulation in normal cell function and suggest that any modulation of its expression could have important pathologic consequences.

We and others demonstrated that exposure of bone marrow stromal cells to common environmental contaminants, such as polycyclic aromatic hydrocarbons (PAHs), adversely affect their function [26-34]. Specifically, the prototypic PAHs, benzo $[a]$ pyrene (B $[a] \mathrm{P})$ and 7,12 dimethylbenz $[a]$ anthracene (DMBA) induce primary or cloned stromal cells to deliver a death signal to adjacent pre- and pro/pre-B cells [28-34]. Induction of this apoptosis signal in stromal cells is dependent on activation of the aryl hydrocarbon receptor (AhR), a cytosolic receptor that is converted into a transcription factor on binding of any one of a number of PAHs, halogenated aromatic hydrocarbons (HAHs), or planar polychlorinated biphenyls (PCBs) [35-37]. Other laboratories demonstrated that $\mathrm{HAH}$, such as 2,4,7,8-tetrachlorodibenzo-p-dioxin (TCDD), suppress the production of bone marrowderived $\mathrm{T}$ cell precursors [38,39], although the role of $\mathrm{AhR}^{+}$bone marrow stromal cells in this process was not evaluated. Interestingly, exposure to AhR ligands has been associated with increased multiple myeloma risk [40-42], suggesting a possible link between AhR activation, aberrant bone marrow stromal cell cytokine production, and plasma cell dyscrasia.

In light of the ability of AhR ligands to target bone marrow stromal cells and the importance of bone marrow stromal cells to blood cell development, we sought to determine if AhR ligands compromise production of bone marrow stromal cell cytokines such as IL-6. To this end, a well-characterized $\mathrm{AhR}^{+}$bone marrow stromal cell line (BMS2) was used to evaluate the effects of a PAH (DMBA) and an HAH (TCDD) on cytokine gene expression induced by the Toll-like receptor-4 (TLR-4) ligand, lipopolysaccacharide (LPS). LPS was chosen for these studies since it up-regulates the production of several bone marrow-derived growth factors, including IL-6, in models of inflammatory cytokine responses [8,11,43-45]. Particular attention was paid to the potential role of the promiscuous transcription factor NF- $\kappa \mathrm{B}$ in $\mathrm{AhR}$ ligand effects since we and others demonstrated a physical and functional interaction between the AhR and the p65 (RelA) subunit of NF- $\kappa \mathrm{B}[46,47]$ and since $\mathrm{NF}-\kappa \mathrm{B}$ plays an important role in regulating IL-6 gene transcription [48].

\section{Methods \\ Chemicals}

TCDD (99.99\% pure) was obtained from Ultra Scientific (North Kingstown, RI). DMBA and Staphylococcus lipopolysaccharide (LPS) were purchased from Sigma Chemical Co. (St. Louis, MO).

\section{Cell culture and treatment}

BMS2, a bone marrow stromal cell line that supports the growth and differentiation of granulocytes, pro/pre-B, and pre-B cells $[8,34]$ was a gift from Dr. P. Kincade (Oklahoma Medical Research Center). BMS2 cells were maintained in DMEM (Mediatech, Washington, DC) supplemented with 5\% fetal calf serum, L-glutamine (Gibco/BRL, Gaithersburg, MD), 2-mercaptoethanol (Sigma Chemical Co) and $25 \mu \mathrm{g} / \mathrm{ml}$ plasmocin (Invivogen, Carlsbad, CA) at $37^{\circ} \mathrm{C}$ and $7.5 \% \mathrm{CO}_{2}$. Cells were passed twice weekly and determined to be mycoplasmafree by a PCR based protocol (Mycoplasma Detection Kit; ATCC, Manassas, VA).

BMS2 cells were plated in antibiotic-free medium for 24 hours prior to treatment with vehicle $(0.01 \%$ ethanol final concentration), 1-10 $\mu \mathrm{M}$ DMBA dissolved in ethanol, or $1 \mathrm{nM}$ TCDD dissolved in DMSO (0.01\% final concentration). One hour later, LPS was added to a final concentration of $1 \mu \mathrm{g} / \mathrm{ml}$. Addition of LPS was delayed one hour to maximize AhR ligand uptake prior to LPS challenge [49]. Cells were harvested at various times thereafter for RNA 
analysis (RNase protection assays; Real-time PCR) or nuclear protein-DNA binding analyses (EMSA), and supernatants were harvested for IL-6 quantitation by ELISA.

\section{RNA isolation}

Culture well-adherent BMS2 cells were removed with $0.05 \%$ trypsin (Sigma), rinsed with PBS, pelleted, and frozen at $-80^{\circ} \mathrm{C}$ until use. Total RNA was isolated using the RNeasy kit (Qiagen; Valencia, CA) or SV Total RNA System (Promega, Madison, WI). RNA was quantitated and samples visualized on an RNA gel to ensure RNA integrity.

\section{Ribonuclease Protection Assay (RPA)}

The RiboQuant Multi-probe RNase Protection Assay System (BD PharMingen, San Diego, CA) was used for RPA experiments. Riboprobes were generated with kit components and fresh $\left[\alpha_{-32}{ }^{32}\right]-U T P 3000 \mathrm{Ci} / \mathrm{mmol}$ (PerkinElmer, Boston, MA) and used within 2 days. Two templates (mCK4 and $\mathrm{mCK} 3 \mathrm{~b}$ ) were tested to screen for changes in genes encoding multiple cytokines: IL-3, IL-6, IL-7, IL-1 1, IFN $\gamma$, TNF $\alpha$, TNF- $\beta$, LT- $\beta$, TGF $\beta$ 1, TGF $\beta 2$, TGF $\beta$ 3, MIF, GM-CSF, M-CSF, G-SF, LIF, and SCF. L32 and GAPDH were also represented as internal standards. Purified probes were mixed with $7-15 \mu \mathrm{g}$ of total RNA and hybridized overnight. After cooling, annealed targets were treated with RNase and the resulting fragments were purified, denatured and resolved on a $4.5 \%$ sequencing gel. The gels were dried completely, exposed to film and quantified with a Molecular Dynamics Phosphor Imager (Amersham Biosciences, Sunnyvale, CA) using Imagequant software (Amersham).

\section{Real-Time PCR}

IL-6 primers were designed to span exon junctions and were tested against genomic templates. PCR products were resolved on agarose gels to show minimal contribution from genomic products or primer dimers. IL- 6 primer sequences were: 5-'CAAGAGACTTCCATCCAGTTGCCT-3' and 5'-TTTCTCATTTCCACGATTTCCCAG-3'. $\beta$-actin primers were 5'-GTCGTCGACAACGGCTCCGGCATGTG3' and 5'-CATTGTAGAAGGTGTGGTGCCAGATC-3'. Total RNA was reverse transcribed into cDNA using TaqMan Reverse Transcription Reagents (PE Applied Biosystems, Foster City, CA). cDNA $(0.01 \mu \mathrm{g})$ was used in the hot start Real-time PCR with SYBR Green PCR Master Mix (PE Applied Biosystems). Real-time PCR was carried out with the ABI Prism 7700 Sequence Detector (PE Applied Biosystems). The PCR conditions were: $95^{\circ} \mathrm{C}$ for $10 \mathrm{~min}, 40$ cycles of $90^{\circ} \mathrm{C}$ for $15 \mathrm{~s}$, and $60^{\circ} \mathrm{C}$ for $1 \mathrm{~m}$, with fluorescence measurements read during each cycle. Fluorescence measurements were used to compare transcripts between samples using the Comparative $\mathrm{C}_{\mathrm{T}}$ Method, a method for determining relative amounts of transcripts based on an internal control when the absolute number of transcripts represented is unknown (PE Applied Biosystems).

\section{ELISA}

BMS2 cells were plated at 25,000 cells/ml in T75 flasks and cultured for 18-24 hours prior to treatment with vehicle ( $0.01 \%$ ethanol or DMSO), $1 \mu \mathrm{M}$ DMBA, or $1 \mathrm{nM}$ TCDD. One hour later, cultures were challenged with 1 $\mu \mathrm{g} / \mathrm{ml}$ LPS. At each time point indicated, $500 \mu \mathrm{l}$ aliquots of BMS2 cell culture supernatants were drawn off and frozen at $-20^{\circ} \mathrm{C}$. ELISAs were carried out with the OptEIA mouse IL-6 ELISA kit (BD Pharmingen) according to the manufacturer's instructions. Supernatant samples were diluted 1:50 and plated in duplicate wells of a 96 well plate. Freshly diluted rIL-6 was used to generate a standard curve on each plate analyzed. The lower limit of detection for this ELISA was $15 \mathrm{pg} / \mathrm{ml}$ IL-6. Plates were read at 450 $\mathrm{nm}$ using a spectrophotometric plate reader. Raw data were corrected against blank wells and converted to $\mathrm{pg} / \mathrm{ml}$ using the standard curve.

\section{NF- $\kappa$ B EMSA}

BMS2 cells were treated in 6-well plates with vehicle or 1 $\mu \mathrm{M}$ DMBA. One hour later, $1 \mu \mathrm{g} / \mathrm{ml}$ LPS or PBS was added to the cultures, and cells were harvested 16 or 24 hours later. Nuclear proteins were extracted as described previously [50]. For determination of NF- $\kappa \mathrm{B}$ activation, a double stranded oligonucleotide containing the $N F-\kappa B$ binding site from the upstream regulatory element of $c$ $m y c$ (5'-GATCCAAGTCCGGGTTTTCCCCAACC-3') [51] was used. The DNA probe was end-labeled using T4 polynucleotide kinase (Promega, Madison, WI) and $\left[\gamma_{-}{ }^{32} \mathrm{P}\right]-$ ATP and was purified using a Centrispin-20 column (Princeton Separations, Adelphia, NJ). EMSAs were performed as follows: ${ }^{32}$ P-labeled DNA ( 0.5 ng, 50,000 cpm) and 2 $\mu \mathrm{g}$ of nuclear protein were combined with buffer (final concentrations: $10 \mathrm{mM}$ Tris- $\mathrm{HCl}, \mathrm{pH} 7.5,1 \mathrm{mM}$ EDTA, $100 \mathrm{mM}$ sodium chloride, $0.5 \mathrm{mM}$ magnesium chloride, $1 \mathrm{mM}$ DTT, $20 \mu \mathrm{g}$ BSA, 10\% glycerol, 0.5\% Triton X-100) and poly dI-dC $(1 \mu \mathrm{g})$ in a final volume of $20 \mu \mathrm{l}$. The mixture was incubated at room temperature for $30 \mathrm{~min}$. The gel was run as above, dried and exposed to film. For quantification, gels were analyzed by phosphorimaging on a Molecular Dynamics Phosphor Imager (Amersham Biosciences). The identity of the NF- $\kappa \mathrm{B}$ subunits was determined by including antibodies (Santa Cruz Biotechnology, Santa Cruz, CA) specific for p50 (sc-114), p52 (sc-848), Rel A (sc-372) or c-Rel (sc-71).

\section{Statistics}

Statistics were calculated using Prism version 3.0 for Macintosh (GraphPad). Data are presented as means $\pm \mathrm{SE}$. Data were analyzed using the Student's T-test or single factor ANOVA's with the Dunnet's multiple comparisons test. 


\section{Results \\ LPS up-regulates cytokine gene induction in bone marrow stromal cells}

Bone marrow stromal cells support the growth and differentiation of early B cells [8]. In previous studies, we demonstrated that cloned bone marrow stromal cell lines, including BMS2 cells, support the growth of primary pre$\mathrm{B}$ and cloned pro/pre-B cells and that treatment of the bone marrow stromal cells with AhR agonists alters their function [28-30,32-34,52]. As a first step in determining if AhR ligands affect stromal cell cytokine production, baseline levels of cytokine mRNAs in BMS2 cells were determined by RNAse protection assays.

RPAs with RNA from BMS2 cells consistently demonstrated significant expression of IL-11, monocyte colony stimulating factor (M-CSF), leukemia inhibitory factor (LIF), IL-6, transforming growth factor- $\beta 1$ (TGF- $\beta 1$ ), TGF- $\beta 3$, and macrophage migration inhibitory factor (MIF) mRNAs (Figure 1). Low but detectable levels of $I L-7$ mRNA also were noted. Addition of LPS consistently induced LIF and IL- 6 mRNAs within 7 hours (Figure 1 and Table 1). GM-CSF and G-CSF mRNAs were clearly induced in two of three and three of four experiments respectively. As suggested by observations made with other stromal cell lines $[44,45]$, these studies demonstrate a potent innate inflammatory cytokine response against bacterial LPS. It should be noted that these studies do not exclude possible LIF or other cytokines at other time points.

\section{The effect of AhR agonists on LPS-mediated IL-6 mRNA induction}

To determine the effect of AhR ligands on LPS-induced cytokine induction, BMS2 cells were treated with vehicle (0.01\% ethanol), $1 \mu \mathrm{M}$ DMBA, or $1 \mathrm{nM}$ TCDD one hour prior to addition of $1 \mu \mathrm{g} / \mathrm{ml}$ LPS. Cells were harvested 8 hours later. RNA was extracted and assayed for cytokine mRNA levels by RPA.

Neither DMBA nor TCDD had a consistent effect on baseline levels of any cytokine mRNA assayed including IL-6 (Figure $2 \mathrm{~A}$ and $2 \mathrm{~B}$ ). This result contrasts with that obtained with vascular endothelial cells in which AhR agonists (coplanar PCBs) alone induced IL-6 [53]. As in previous experiments, LPS significantly induced LIF and IL-6 mRNAs (Figure 2A). (RNA encoding GM-CSF and GCSF also were increased, although bands representing these RNAs were sometimes difficult to see when underexposing blots to emphasize $I L-6$ levels (e.g. Figure 2)) Importantly, in five experiments, both DMBA and TCDD significantly reduced the LPS-mediated $I L-6$ mRNA increase in BMS2 cells (Figure 2A and 2B; $\mathrm{p}<0.05$ ). Other genes activated by LPS, i.e. LIF, GM-CSF, and G-CSF, were not affected by either of these AhR agonists (Figure 2A and data not shown) demonstrating the selectivity of AhR agonist-mediated effects on stromal cells.

Kinetics studies were performed using real-time PCR as a readout to quantify this change in $I L-6$ mRNA levels. As seen in Figure 3, IL-6 mRNA levels increased within $1 \mathrm{hr}$ of LPS stimulation and reached a plateau at the four hour time point. Inclusion of DMBA in the cultures reduced $I L$ 6 mRNA induction significantly at every time point, including at 1 hour $(\mathrm{p}<0.02)$. These results are consistent with those obtained by RPA and demonstrate that AhR ligands suppress $I L-6$ mRNA levels by approximately $40-$ $60 \%$.

\section{DMBA and TCDD significantly abrogate LPS-induced IL-6 production}

The results described above indicate consistent suppression of LPS-mediated $I L-6$ mRNA induction. To determine if this decrease in steady state mRNA is reflected in a proportional decrease in secreted IL-6 protein levels, BMS2 cells were cultured for $18 \mathrm{hrs}$ prior to addition of vehicle, $1 \mu \mathrm{M}$ DMBA, or $1 \mathrm{nM}$ TCDD. One hour later, cultures were treated with PBS (to assay effects of AhR ligands on background IL-6 levels) or challenged with $1 \mu \mathrm{g} / \mathrm{ml}$ LPS (i.e. time zero). Culture supernatants were harvested at time zero and 6-72 hours thereafter and assayed by ELISA for IL-6 levels.

Supernatants from BMS2 cultures established 18-24 hrs previously contained approximately $700 \mathrm{pg} / \mathrm{ml}$ IL-6 (Figure 4A). Addition of DMBA had no effect on IL-6 levels at any time point assayed. However, TCDD significantly ( $\mathrm{p}$ $<0.05$ ) reduced the background level of IL- 6 as early as 24 hrs after its addition to the cultures. Control experiments in which recombinant IL- 6 was assayed in the presence of TCDD indicated that TCDD did not interfere with the IL6-specific ELISA (data not shown). Therefore, TCDD is capable of reducing baseline IL- 6 protein levels early in the response to LPS.

A significant increase in secreted IL-6 levels was seen as early as 6 hours after LPS treatment (Figure 4B). IL-6 levels continued to rise throughout the 72 hour period after LPS exposure. However, this LPS-dependent increase in secreted IL-6 was suppressed in cultures containing either DMBA or TCDD, with TCDD suppressing IL-6 levels as much as $88 \%$ at the 72 hour time point. Neither TCDD nor DMBA affected BMS2 proliferation as all cultures reached confluency at the same time (approximately 96 hrs after plating). These data demonstrate that activation of the AhR has a significant effect on the ability of bone marrow stromal cells to produce IL-6. Furthermore, the profound decrease in IL- 6 protein levels in TCDD-exposed cells exhibiting only a $40-60 \%$ decrease in $I L-6$ mRNA 

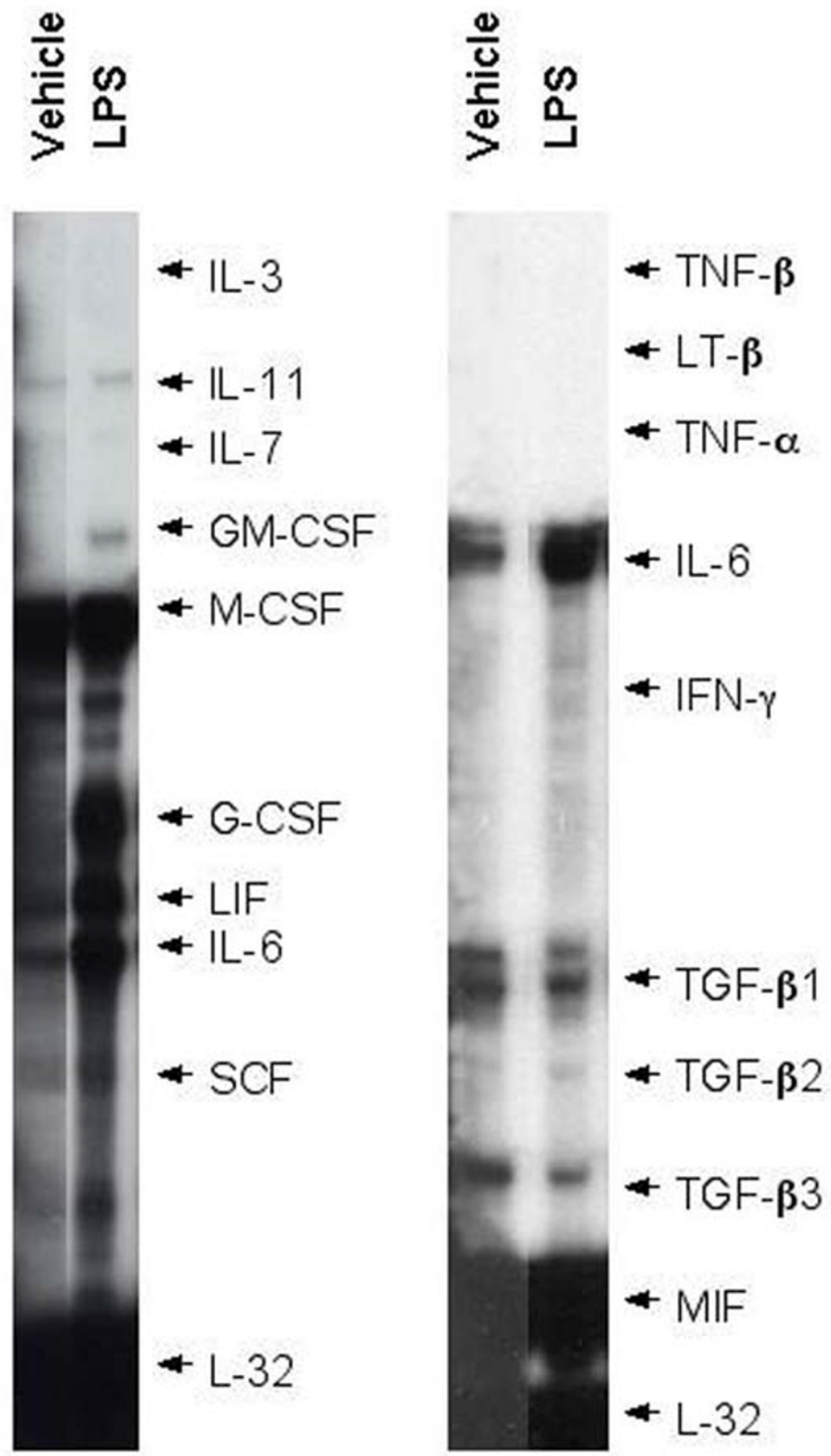

Figure I

LPS induces GM-CSF, G-CSF, LIF, and IL-6 mRNAs in bone marrow stromal cells. BMS2 (bone marrow stromal) cells were cultured in the presence of I $\mu \mathrm{g} / \mathrm{ml}$ LPS for eight hours. Cells were harvested, RNA was extracted, and mRNAs specific for several cytokines were assayed by RNAse protection assays (RPAs). Representative data from two experiments (seven total) are presented. 
Table I: LPS induces GM-SCF, G-CSF, LIF, and IL-6 mRNAs in bone marrow stromal cells

\begin{tabular}{cccc}
\hline Gene & N & Mean Fold Change \pm SE & P-value \\
\hline IL-II & 4 & $1.3 \pm 0.2$ & 0.27 \\
IL-7 & 5 & $0.9 \pm 0.2$ & 0.58 \\
GM-CSF & 3 & Increasedc & - \\
G-CSF & 4 & Increasedc & - \\
LIF & 5 & $5.7 \pm 1.2$ & $0.02^{*}$ \\
IL-6 & 7 & $7.0 \pm 1.5$ & $0.01^{*}$ \\
SCF & 4 & $1.1 \pm 0.1$ & 0.40 \\
M-CSF & 5 & $1.0 \pm 0.1$ & 0.79 \\
TGF- $\beta$ I & 2 & $1.2,1.4$ & 0.26 \\
TGF- $\beta 3$ & 2 & $0.8,0.9$ & 0.18 \\
MIF & 2 & $0.9,1.0$ & 0.52 \\
\hline
\end{tabular}

\begin{abstract}
a From the Ribonuclease Protection Assays (RPAs), mean fold-change was determined by normalizing the optical density band of the LPS-treated sample to the housekeeping gene GAPDH or L-32, then expressing it relative to the optical density of the normalized band from the vehicle-treated sample. ${ }^{b}$ Based on one-sample t-test to determine whether mean was significantly different from maximum LPS induction $(\mu=1.0)$. ${ }^{c}$ Expression of GM-CSF and G-CSF was sometimes undetectable in unstimulated cells, thus the LPS-induced expression could not be described appropriately as "fold change" * $p<0.05$
\end{abstract}

levels, suggests that at least this AhR ligand may suppress IL-6 production at more than just the RNA level.

\section{NF- $\kappa$ B activation correlates with IL-6 mRNA levels}

LPS-induced $I L-6$ gene transcription in murine monocytes is controlled primarily by NF- $\mathrm{BB}$, although other transcription factors may play minor roles [48]. Since we and others have demonstrated interactions between the AhR and the NF- $\kappa B$ signaling pathways $[46,47,53,54]$, it was important to determine if activation of the AhR influenced NF- $\kappa B$ activity in bone marrow stromal cells. To this end, BMS2 cells were treated with vehicle or DMBA one hour prior to exposure to LPS as in previous experiments. Cells were harvested 16-24 hours later. Nuclear proteins were extracted and assayed in electromobility shift assays (EMSAs) for binding of nuclear proteins to a radiolabelled NF- $\kappa \mathrm{B}$ probe consisting of the NF- $\kappa \mathrm{B}-$ binding upstream regulatory element of the $c-m y c$ promoter [29].

Data presented in Figure 5A extend previous studies performed with monocytes by demonstrating that LPS induces NF-kB-DNA binding in bone marrow stromal cells. The ability to supershift NF-kB-DNA complexes with antibodies specific for the p50 or RelA/p65 subunits of NF- $\mathrm{KB}$ (Figure $5 \mathrm{~B}$ ) indicates that LPS primarily activates a conventional NF- $\mathrm{KB}$ complex probably consisting of p50/ RelA. While DMBA alone had no effect on the low baseline levels of NF-kB-DNA binding, it modestly suppressed the NF- $\kappa B$ activity induced with LPS (Figure 5A). Quantification of normalized band densities indicated that DMBA significantly decreased LPS-induced NF-KB-DNA binding by $33 \%(\mathrm{p}<0.05)$ (Figure $5 \mathrm{C})$. These data demonstrate a correlation between NF- $\mathrm{BB}$ activity and $I L-6$ mRNA levels.

\section{Discussion}

The present studies were designed to evaluate the ability of AhR ligands to influence a spectrum of bone marrow stromal cell cytokines. In this system, exposing AhR+ stromal cells to LPS induced an inflammatory response characterized in part by up-regulation of IL-6 Any environmental chemical capable of compromising this response has the potential to disrupt the regulation of many important stromal cell functions, including generation of inflammatory responses in general and the elaboration of several cytokines, including IL-6, to regulate blood cell development in particular.

Previously, we demonstrated that DMBA and TCDD, two prototypic AhR ligands, activate the AhR in BMS2 cells $[28,34]$. In studies presented here we demonstrate that both TCDD and DMBA suppress IL-6 production at least through the reduction of steady state IL- 6 mRNA levels. The reduction in IL- 6 mRNA levels does not exclude the possibility that these AhR ligands also suppress IL-6 protein secretion or stability. The specificity of this toxicity is underscored by the failure of these AhR agonists to affect either the baseline or LPS-induced levels of mRNAs specific for several other cytokines at the time points assayed here, although modulation of these or other cytokines at other time points cannot be excluded. This result also indicates that the observed changes in IL- 6 do not result from overt toxicity or suppression of cell growth by AhR agonists.

In our continuing investigations into interactions between AhR and NF- $\kappa B$ signaling pathways [47], we sought to determine if AhR signaling influences NF- $\kappa B$ activity in bone marrow stromal cells. An added incentive 


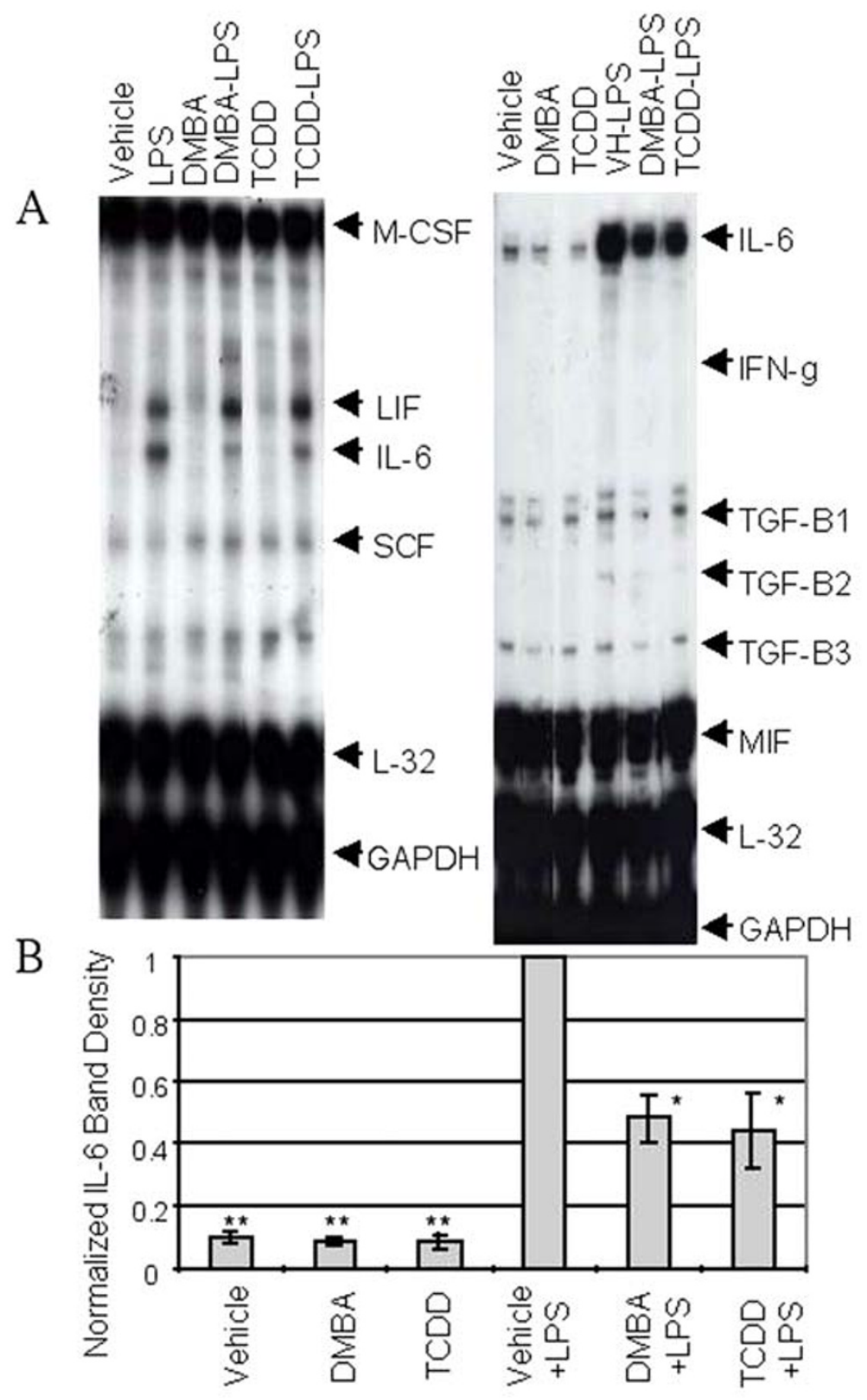

\section{Figure 2}

LPS-induced IL-6 mRNA induction is inhibited by DMBA and TCDD. BMS2 cells were pre-treated with vehicle (0.0 I\% ethanol), I $\mu$ M DMBA, or I nM TCDD for one hour prior to challenge with I $\mu \mathrm{g} / \mathrm{ml} L P S$. Eight hours later, cells were harvested, RNA was extracted, and cytokine-specific mRNAs were assayed by RPA. (A) Representative data from two experiments (seven total) are presented. (B) Optical densities of bands corresponding to each cytokine mRNA were normalized to L-32 band densities and then expressed relative to the maximal response seen with LPS-plus-vehicle-treated cultures. Data represent the means \pm SE from 4-5 independent experiments. One-sample t-tests were conducted to compare relative expressions to the theoretical $\mu=I$ (maximum response in LPS-plus-vehicle-treated cultures). * Significantly different from cultures treated with LPS and vehicle, $\mathrm{p}<0.05$; ** Significantly different from cultures treated with LPS and vehicle $\mathrm{p}<0.000$ I. 


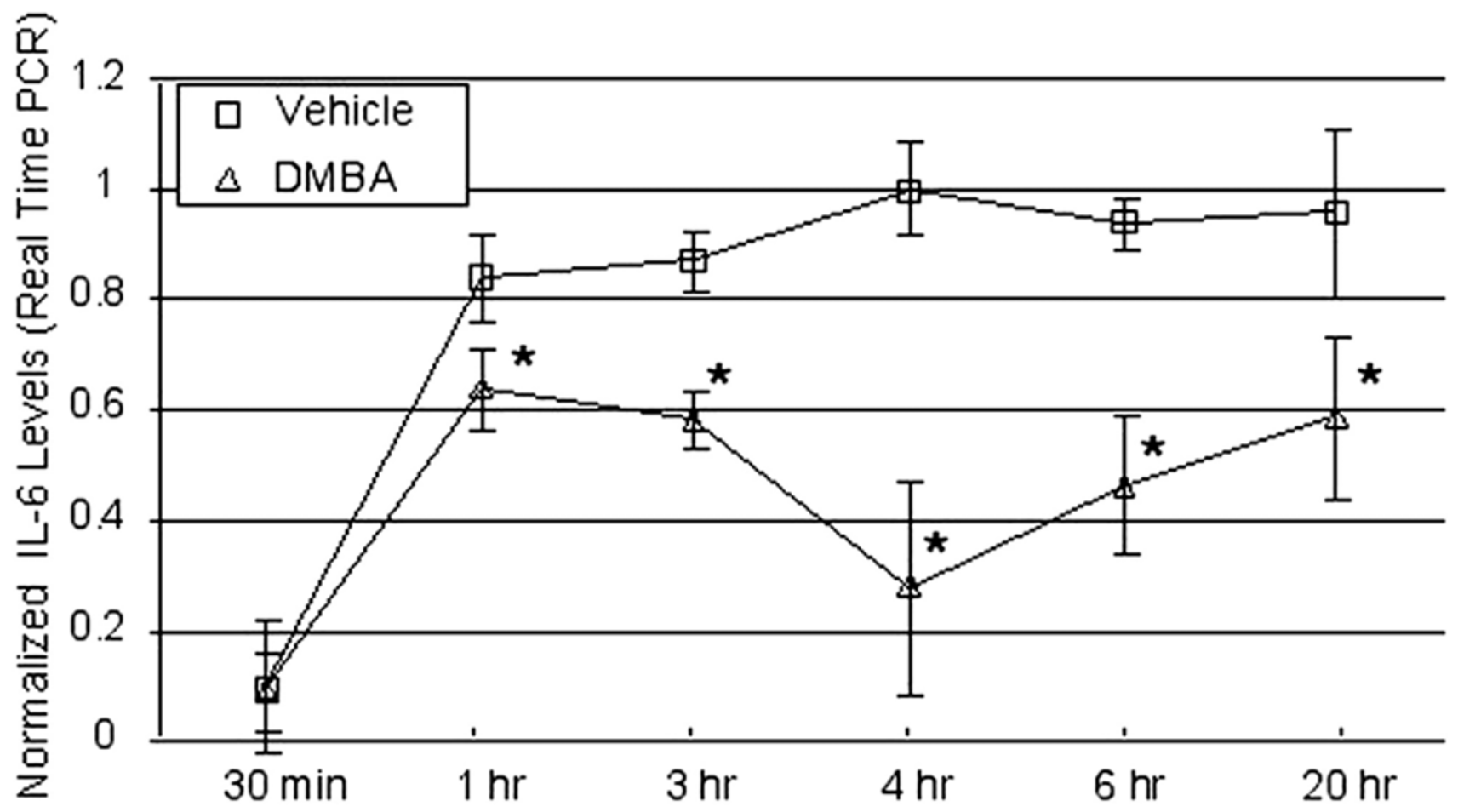

Figure 3

Kinetics of DMBA-mediated suppression of IL-6 mRNA levels measured byReal-time PCR. BMS2 cells were pre-treated in triplicate with vehicle $(0.01 \%$ ethanol) or I $\mu$ M DMBA I hour prior to challenge with I $\mu g / \mathrm{ml}$ LPS. At various points thereafter, cells in individual wells were harvested separately, RNA was extracted, and cytokine-specific mRNAs were quantified by real-time PCR. Data represent means \pm SE of IL-6 mRNA levels (number of PCR cycles for half-maximal amplification) normalized to $\beta$-actin levels according to the Comparative $\mathrm{C}_{\mathrm{T}} \$$ Method (PE Applied Biosystems) and expressed relative to maximal IL6 levels in LPS-plus-vehicle-treated cultures at the 4 hour time point. Representative data from a total of three experiments are shown. *Statistically different than vehicle-treated controls, $\mathrm{p}<0.02$ (paired $t$ test).

for these studies was provided by the observation that the IL- 6 gene promoter contains an NF- $\kappa \mathrm{B}$ binding site which plays a major role in regulating LPS-induced IL-6 transcription [55-57]. Indeed, EMSAs indicated a profound increase in NF- $\mathrm{KB}$ activity following LPS exposure. This induction was suppressed modestly (33\%) but significantly $(\mathrm{p}<0.05)$ by DMBA. These results suggest a possible mechanism by which the AhR may regulate IL-6 transcription, i.e. suppression of NF- $\kappa \mathrm{B}$ signaling.

The AhR ligand-mediated decrease in NF- $\kappa \mathrm{B}$ activity documented here differs from results obtained with other cell types. For example, coplanar PCBs, which can activate the AhR, increase IL-6 production in endothelial cells [58]. Furthermore, TCDD increases both AP-1 and NF- $\kappa$ B binding to their cognate response elements in hepatoma cells $[59,60]$. In the latter example, NF- $\kappa \mathrm{B}$ up-regulation involved an increase in binding of p50 homodimers to a consensus NF- $\kappa \mathrm{B}$ nucleotide sequence. Unlike the p50/
RelA-containing complexes implicated in the present studies (Figure 5B), p50 homodimers may actually block p50/p65-dependent gene activation [61]. Indeed, p50/ RelA dimers are well known to activate gene transcription $[29,51,62,63]$. Therefore, its suppression by AhR ligands is likely to have important biological consequences.

Finally, the results presented here demonstrate the ability of AhR ligands to affect cytokine production in vitro. Several studies indicate cytokine dysregulation in vivo following exposure to TCDD or PAH, although the nature of these changes differs significantly between systems. In vivo exposure to TCDD in and of itself increases serum TNF- $\alpha$ levels [64] and the administration of a TNF-immunoglobulin fusion protein [64] or TNF- $\alpha$-specific antibodies ameliorates TCDD-mediated inflammatory responses [65]. Furthermore, TCDD exacerbates the TNF-mediated inflammatory responses to LPS in vivo [66]. In contrast, 

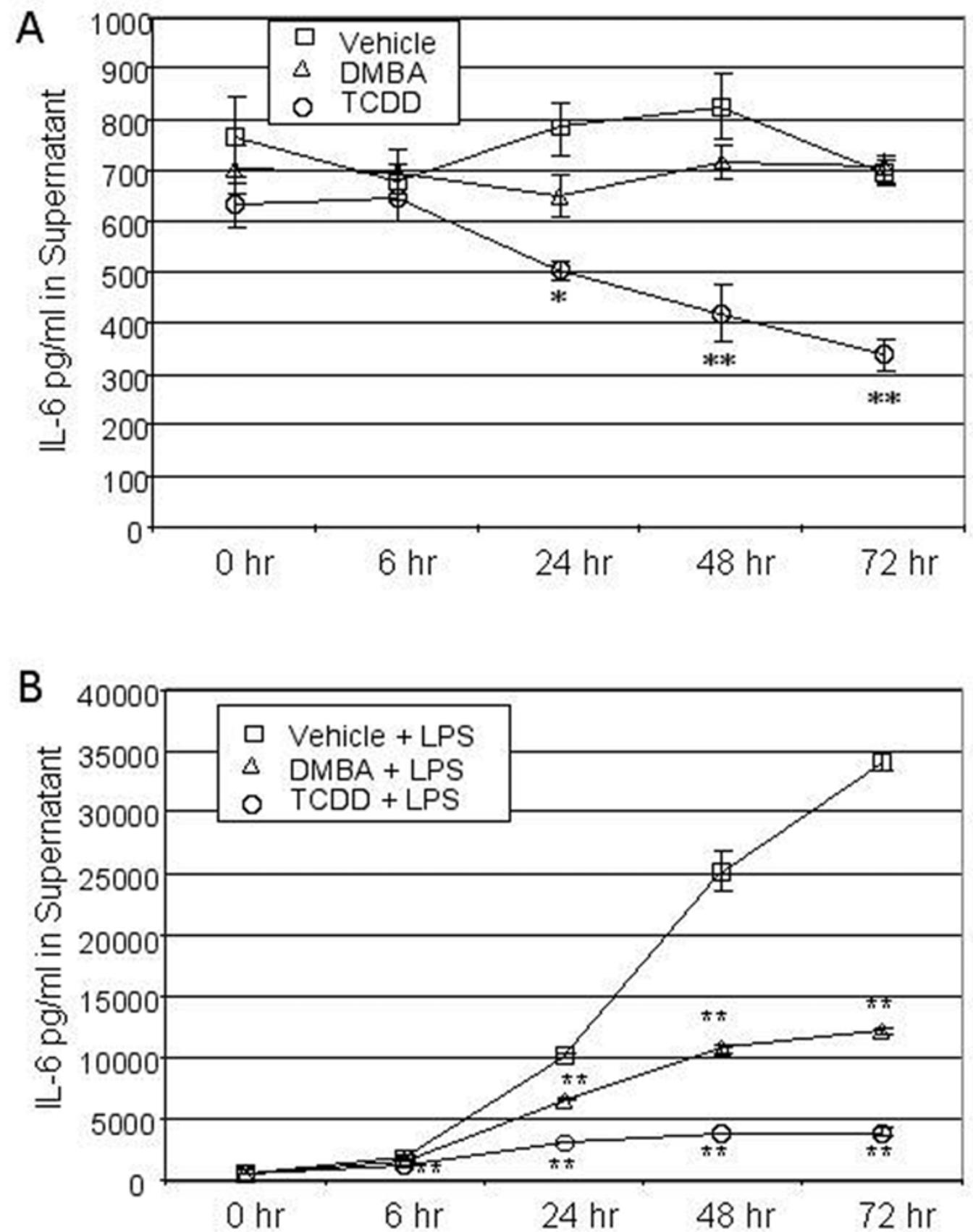

\section{Figure 4}

DMBA and TCDD suppress LPS-induced IL-6 protein production. BMS2 cells were plated 250,000 cells per flask and cultured for 18-24 hours prior to treatment with vehicle $(0.01 \%$ ethanol), I $\mu$ M DMBA, or I nM TCDD. One hour later, cultures were challenged with I $\mu \mathrm{g} / \mathrm{ml}$ LPS as indicated. Supernatants were sampled at various times thereafter and assayed by ELISA for IL-6 protein levels. IL-6 concentrations were determined by comparison to a recombinant IL-6 standard curve. Data are presented as means \pm SE from three independent experiments. IL- 6 levels for each time point within an experiment were measured in triplicate (A) IL-6 levels in groups not challenged with LPS. *Significantly different from vehicle control, $P<0.05$ (oneway ANOVA and Dunnett's multiple comparisons test). **Significantly different from vehicle control, $\mathrm{p}<0.0 \mathrm{I}$. (B) IL-6 levels in groups challenged with LPS. *Significantly different from corresponding LPS-plus-vehicle wells $(p<0.05)$. **Significantly different from vehicle or vehicle-plus-LPS wells, $p<0.0$ I. 

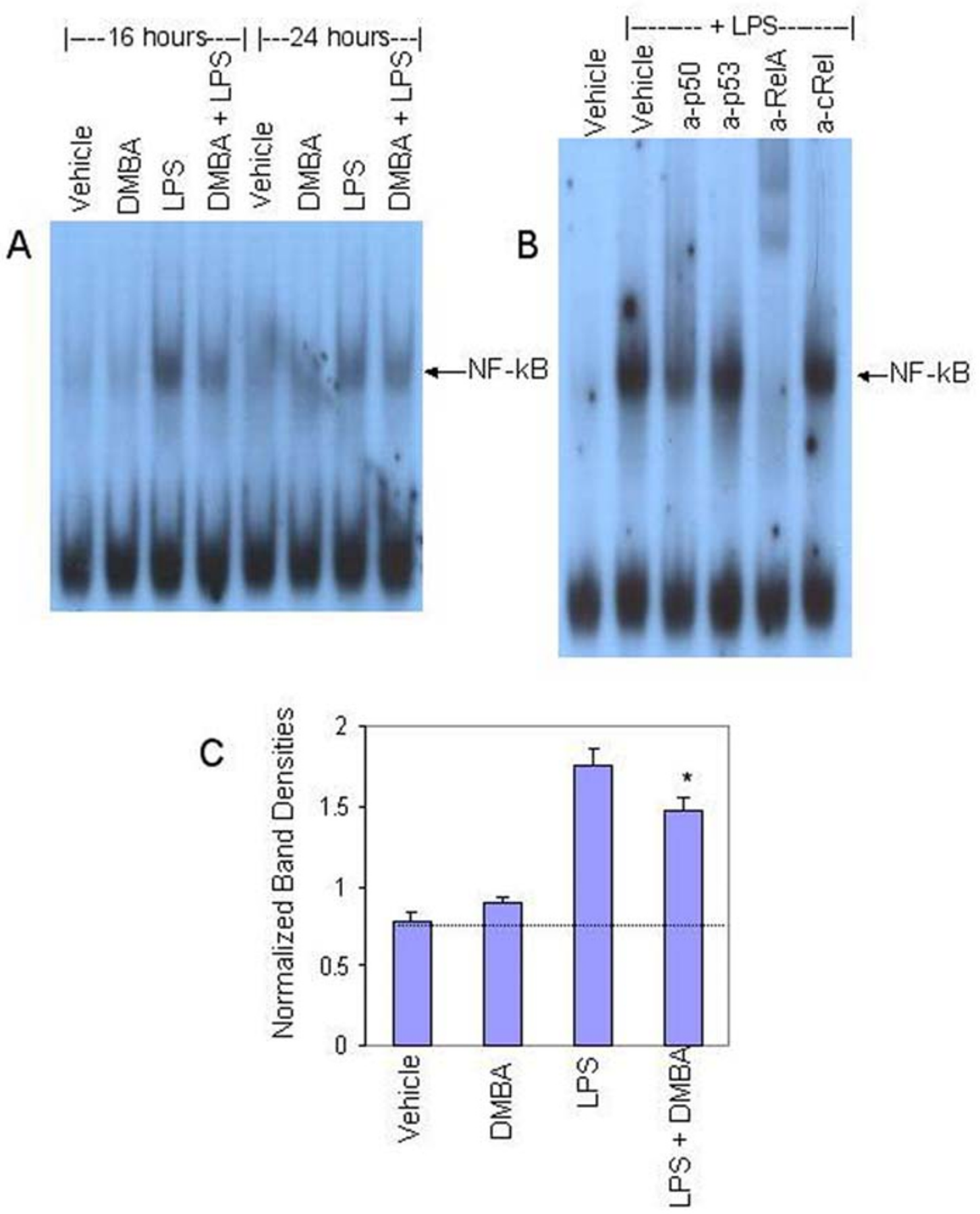

\section{Figure 5}

DMBA inhibits LPS-induced NF- $\kappa$ B-DNA binding. BMS2 cells were left untreated (naïe) or were pre-treated with vehicle $(0.01 \%$ ethanol) or I $\mu$ M DMBA for one hour prior to challenge with I $\mu \mathrm{g} / \mathrm{ml}$ LPS. Cells were harvested 16 and $24 \mathrm{hrs}$ later. Nuclear proteins were extracted and analyzed by EMSA for binding to an NF- $\kappa$ B probe derived from the c-myc upstream regulatory element. (A) Data from a representative experiment (three total) are presented. An arrow indicates the NF- $\kappa B$-specific band. (B) EMSAs were performed with nuclear extracts from BMS2 cells treated for 30 min with LPS in the presence of antibodies specific for the p50, p53, RelA (p65), or c-Rel subunits of NF- $\kappa B$. (C) Quantification of NF- $\kappa B-D N A$ binding in nuclear extracts treated for 16-24 hrs. NF- $\kappa B$ band densities were normalized to untreated controls within the same experiments. **Significantly different from LPS-plus vehicle-treated control, $\mathrm{p}<0.05$ (paired t-test). 
TCDD injection suppresses IL- 6 responses of splenic T lymphocytes to a protein antigen [67].

Results of in vivo exposures to AhR ligands may even differ between tissues. For example, TCDD injection results in a significant decrease in $I L-18$ mRNA in the thymus but a significant increase in the spleen $[68,69]$. Similarly, IFN- $\gamma$ levels in lymph nodes from TCDD-treated and virusinfected mice decrease while levels in the lung increase 10 fold [70]. Clearly, the effects of AhR ligands in vivo are varied and complex, likely involving interactions between many cell types and cytokine feedback loops. Significantly, none of these studies have evaluated inflammatory cytokine production in the bone marrow. Future experiments from our laboratory will address this gap in knowledge about AhR ligand toxicity.

\section{Conclusion}

The studies presented here demonstrate that prototypic AhR agonists, including an environmentally ubiquitous dioxin, specifically suppress the LPS-induced production of IL- 6 by bone marrow stromal cells. The more potent AhR agonist, TCDD, also reduced baseline levels of IL-6 protein. Inhibition of IL-6 production in response to LPS occurs at least at the level of mRNA expression and may involve down-regulation of NF- $\kappa \mathrm{B}$, a transcription factor known to play a major role in regulating $I L-6$ gene transcription. Collectively, the results demonstrate the potential for common environmental AhR ligands to compromise the ability of bone marrow stromal cells to generate important inflammatory responses and to support production of blood cell lineages.

\section{Abbreviations}

AhR, aryl hydrocarbon receptor/transcription factor; B $[a] \mathrm{P}$, benzo [a]pyrene; DMBA, 7,12-dimethylbenz [a] anthracene; G-CSF, granulocyte colony stimulating factor; GM-CSF, granulocyte/monocyte colony stimulating factor; $\mathrm{HAH}$, halogenated aromatic hydrocarbons; IFN- $\gamma$, interferon- $\gamma$; LIF, leukemia inhibitory factor; LPS, Staphylococcus-derived lipopolysaccharide; MIF, macrophage migration inhibitory factor; $\mathrm{PAH}$, polycyclic aromatic hydrocarbon; TCDD， 2,3,7,8-tetrachlorodibenzo- $p$ dioxin; TLR, Toll-like receptor(s); TNF, tumor necrosis factor; TGF, transforming growth factor

\section{Competing Interests}

None declared.

\section{Authors' Contributions}

B.A.J. designed and performed experiments summarized in Figures 1,2,3,4 and Table 1 with the assistance of R.J.L. and shared responsibilities for planning the project and drafting this manuscript with D.H.S J.J.S. performed experiments summarized in Figure 5. D.H.S. proposed the general field of study, participated in the design of experiments, supervised data interpretation, and obtained funding to support the work.

\section{Acknowledgements}

The authors thank llga Wohlrab for performing all the administrative duties related to this project and to Maryam Shansab for assisting in manuscript preparation. Supported by NIH ROI-ES06086, Superfund Basic Research Grant \#IP42ES-0738I, and POI HL 68705.

\section{References}

I. Kittler EL, McGrath H, Temeles D, Crittenden RB, Kister VK, Quesenberry PIJ.: Biologic significance of constutive an subliminal growth factor production by bone marrow stroma. Blood 1992, 79:3168-3178.

2. Robledo MM, Teixido J: TGF-b I binding proteins on human bone marrow stromal cells. Leuk Lymphoma 1997, 27:509-5 I5.

3. Gupta D, Treon SP, Shima Y, Hideshima T, Podar K, Tai YT, Lin B, Lentzsch S, Davies FE, Chauhan D, Schlossman RL, Richardson P, Ralph P, Wu L, Payvandi F, Muller G, Stirling DI, Anderson KC: Adherence of multiple myeloma cells to bone marrow stromal cells upregulates vascular endothelial growth factor secretion: therapeutic applications. Leukemia 2001, 15:1950-1961.

4. Akiyama M, Hideshima T, Hayashi T, Tai YT, Mitsiades CS, Mitsiades N, Chauhan D, Richardson P, Munshi NC, Anderson KC: Cytokines modulate telomerase activity in a human multiple myeloma cell line. Cancer Res 2002, 62:3876-3882.

5. Petrucci M, Ricciardi MR, Gregorj C, Ciapponi L, Savino R, Ciliberto G, Tafuri A: Effects of IL-6 variants in multiple myeloma: growth inhibition and induction of apoptosis in primary cells. Leuk Lymphoma 2002, 43:2369-2375.

6. Aoyama K, Oritani K, Yokota T, Ishikawa J, Nishiura T, Miyake K, Kanakura Y, Tomiyama Y, Kincade PW, Matsuzawa Y: Stromal cell CD9 regulates differentiation of hematopoietic stem/progenitor cells. Blood 1999, 93:2586-2594.

7. Hirose J, Kouro T, Igarashi H, Yokota T, Sakaguchi N, Kincade PW: A developing picture of lymphopoiesis in bone marrow. Immunol Rev 2002, 189:28-40.

8. Kincade PW, Lee G, Pietrangeli CE, Hayashi S-I, Gimble JM: Cells and molecules that regulate $B$ lymphopoiesis in bone marrow. Ann. Rev. Immunol. 1989, 7: I II.

9. Pietrangeli CE, Hayashi S, Kincade PW: Stromal cell lines which support lymphocyte growth: characterization, sensitivity to radiation and responsiveness to growth factors. Eur J Immunol 1988, 18:863-872.

10. Billiau A: BSF-2 is not just a differentiation factor. Nature I986, 324:415-419.

II. Gimble JM, Pietrangeli C, Henley A, Dorheim MA, Silver J, Namen A, Takeichi M, Goridis C, Kincade PW: Characterization of murine bone marrow and spleen-derived stromal cells: analysis of leukocyte marker and growth factor mRNA transcript levels. Blood 1989, 74:303-3II.

12. Taga T, Kishimoto T: Role of a two-chain IL-6 receptor system in immune and hematopoetic cell regulation. Crit Rev Immunol 1992, I I:265-280.

13. Kopf M, Ramsay A, Brombacher F, Baumann H, Freer G, Galanos C, Guteirrez-Ramos JC, Kohler G: Pleiotropic defects of IL-6-deficient mice including early hematopoiesis, $T$ and $B$ cell function, and acute phase responses. Ann N Y Acad Sci 1995, 762:308-318.

14. Kawano MM, Ishikawa H, Tsuyama N, Abroun S, Liu S, Li FJ, Otsuyama K, Zheng X: Growth mechanism of human myeloma cells by interleukin-6. Int J. Hematol 2002, 76:329-333.

15. Wols H.A. Minges, Underhill GH, Kansas GS, Witte PL: The role of bone marrow-derived stromal cell sin the maintenence of plasma cell longevity. J. Immunol 2002, I 69:42 I3-422I.

16. Tu CX, Gu JS, Lin XR: Increased interleukin-6 and granulocytemacrophage clony stimulating factor levels in the sera of patients with non-segmental vitiligo. J Dermatol Sci 2003, 3 I:73-78.

17. Finck BK, Chan B, Wofsy D: Interleukin 6 promotes murine lupus in NZB/NZW F I mice. J Clin Invest 1994, 94:585-59I. 
18. McMurray RW, Hoffman RW, Nelson W, Walker SE: Cytokine mRNA expression in the B/W mouse model of systemic lupus erythematosus--analyses of strain, gender, and age effects. Clin Immunol Immunopathol 1997, 84:260-268.

19. Nakahara H, Song J, Sugimoto M, Hagihara K, Kishimoto T, Yoshizaki $\mathrm{K}$, Nishimoto N: Anti-interleukin-6 receptor antibody therapy reduces vascular endothelial growth factor production in rheumatoid arthritis. Arthritis Rheum 2003, 48:I52I-I529.

20. Heinrich PC, Behrmann I, Haan S, Hermanns HM, Muller-Newen G Schaper F: Principles of interleukin (IL)-6-type cytokine signalling and its regulation. Biochem J 2003, 374:I-20.

21. Jourdan M, Veyrune JL, Vos JD, Redal N, Couderc G, Klein B: A major role for Mcl-I antiapoptotic protein in the IL-6induced survival of human myeloma cells. Oncogene 2003, 22:2950-2959.

22. Hirata T, Shimazaki C, Sumikuma T, Ashihara E, Goto H, Inaba T, Koishihara $Y$, Nakagawa M: Humanized anti-interleukin- 6 receptor monoclonal antibody induced apoptosis of fresh and cloned human myeloma cells in vitro. Leuk Res 2003, 27:343-349.

23. Jee SH, Shen SC, Chiu HC, Tsai WL, Kuo ML: Overexpression of interleukin-6 in human basal cell carcinoma cell lines increases anti-apoptotic activity and tumorigenic potency. Oncogene 200I, 20:198-208.

24. An J, Sun Y, Sun R, Rettig MB: Kaposi's sarcoma-associated herpesvirus encoded vFLIP induces cellular IL-6 expression: the role of the NF-kappaB and JNK/API pathways. Oncogene 2003, 22:337|-3385.

25. Kallen $\mathrm{KJ}$ : The role of transsignalling via the agonistic soluble IL-6 receptor in human diseases. Biochim Biophys Acta 2002, I 592:323-343

26. Heidel SM, Holston K, Buters JT, Gonzalez FJ, Jefcoate CR, Czupyrynski CJ: Bone marrow stromal cell cytochrome P450IBI is required for pre-B cell apoptosis induced by 7,12-dimethylbenz[a]anthracene. Mol Pharmacol 1999, 56:1317-1323.

27. Page TJ, O'Brien S, Jefcoate CR, Czuprynski CJ: 7,I2-Dimethylbenz[a]anthracene induces apoptosis in murine pre-B cells through a caspase-8-dependent pathway. Mol Pharmacol 2002, 62:313-319.

28. Mann KK, Matulka RA, Lawrence BP, Kerkvliet NI, Sherr DH: The role of cytochrome P-450 enzymes in 7,12-dimethylbenz[a]anthracene-induced apoptosis. Toxicol. Appl. Pharmacol. 1999, I61:10-22.

29. Mann KK, Doerre S, Sherr DH, Quadri S: The Role of NF-kB as a survival factor in environmental chemical-induced pre-B cell apoptosis. Molec. Pharmacol. 200I, 59:302-309.

30. Near RI, Mann KK, Matulka RA, Shneider AM, Gogate SU, Trombino AF, Sherr DH: Regulation of pre-B cell apoptosis by aryl hydrocarbon receptor/transcription factor-expressing stromal/ adherent cells. Proc. Soc. Exp. Biol. Med. 1999, 22 1:242-252.

31. Allan LL, Mann KK, Matulka RA, Ryu H-Y, Schlezinger JL, Sherr DH: Bone marrow interactions in polycyclic aromatic hydrocarbon-induced pro/pre-B cell apoptosis. In Press. Toxicol. Sci. 2003.

32. Ryu H-Y, Mann KK, Schlezinger JJ, Jensen B, Sherr DH: Environmental chemical-induced pro/pre-B cell apoptosis: Analysis of cMyc, p27KipI, and p2IWAFI reveals a death pathway distinct from clonal deletion. J. Immunol. 2003, I70:4897-4904.

33. Yamaguchi K, Matulka RA, Shneider A, Toselli P, Trombino AF, Yang S, Hafer LJ, Mann KK, Tao X-J, Tilly JL, Near R, Sherr DH: Induction of pre-B cell apoptosis by 7,12 dimethylbenz[a]anthracene in long term bone marrow cultures. Toxicol. Appl. Pharmacol. 1997, I 47:190-203.

34. Yamaguchi K, Near RI, Matulka RA, Shneider A, Toselli P, Trombino $\mathrm{AF}$, Sherr $\mathrm{DH}$ : Activation of the aryl hydrocarbon receptorl transcription factor and stromal cell-dependent pre-B cell apoptosis. J. Immunol. 1997, I 58:2165-2173.

35. Denison MS, Vella LM, Okey AB: Structure and function of the Ah Receptor for 2,3,7,8-tetrachlorodibenzo-p-dioxin. The Journal of Biological Chemistry 1986, 26 I:3987-3995.

36. Hogenesch JB, Chan WK, Jackiw VH, Brown RC, Gu YZ, Pray-Grant $M$, Perdew GH, Bradfield CA: Characterization of a subset of the basic-helix-loop-helix-PAS superfamily that interacts with components of the dioxin signaling pathway. I Biol Chem 1997, 272:858I-8593.
37. Perdew GH: Association of the Ah receptor with the $90-\mathbf{k D a}$ heat shock protein. The Journal of Biological Chemistry 1988, 263: I3802-13805.

38. Murante FG, Gasiewicz TA: Hemopoietic progenitor cells are sensitive targets of 2,3,7,8-tetrachlorodibenzo-p-dioxin in C57BL/6] mice. Toxicol Sci 2000, 54:374-383.

39. Staples JE, Murante FG, Fiore NC, Gasiewicz TA, Silverstone AE: Thymic alterations induced by 2,3,7,8-tetrachlorodibenzo-pdioxin are strictly dependent on aryl hydrocarbon receptor activation in hemopoietic cells. J Immunol 1998, 160:3844-3854.

40. Schwartz GG: Multiple myeloma: clusters, clues, and dioxins. Canc. Epi., Biomarkers, Prev. 1997, 6:49-56.

4I. Bertazzi PA, Pesatori AC, Consonni D, Tironi A, Landi MT, Zocchetti C: Cancer incidence in a population accidentally exposed to 2,3,7,8-tetrachlorodibenzo-para-dioxin. Epidemiol. 1993, 4:398-406.

42. Bertazzi PA, Zocchetti C, Guercilena S, Consonni D, Tironi A, Landi MT, Pesatori AC: Dioxin exposure and cancer risk: A I5-year mortality study after the "Seveso accident". Epidemiol. 1997, 8:646-652.

43. Schilling JD, Martin SM, Hung CS, Lorenz RG, Hultgren SJ: Toll-like receptor 4 on stromal and hematopoietic cells mediates innate resistance to uropathogenic Escherichia coli. Proc Nat Acad Sci U S A 2003, 100:4203-4208.

44. Lorgeot V, Rougier F, Fixe P, Cornu E, Praloran V, Denizot Y: Spontaneous and inducible production of leukaemia inhibitory factor by human bone marrow stromal cells. Cytokine 1997, 9:754-758.

45. Rougier F, Cornu E, Praloran V, Denizot Y: II-6 and IL-8 production by human bone marrow stromal cells. Cytokine 1998, 10:93-97.

46. Tian $Y, K e S$, Denison MS, Rabson AB, Gallo MA: Ah receptor and NF-kB interactions, a potential mechanism for dioxin toxicity. J. Biol. Chem. 1999, 274:510-515.

47. Kim DW, Gazourian L, Quadri SA, Sherr* DH, Sonenshein* GE: The aryl hydrocarbon receptor/transcription factor (AhR) and the Rel A nuclear factor-kB subunit cooperate to transactivate the c-myc promoter. Oncogene 2000, 19:5498-5506 *Equal contributions by the Sherr and Sonenshein laboratories.

48. Dendorfer U, Oettgen P, Libermann TA: Interleukin-6 Gene Expression by Prostaglandins and Cyclic AMP Mediated by Multiple Regulatory Elements. Am J Ther 1995, 2:660-665.

49. Hestermann EV, Stegeman JJ, Hahn ME: Serum alters the uptake and relative potencies of halogenated aromatic hydrocarbons in cell culture bioassays. Toxicol Sci 2000, 53:316-325.

50. Schlezinger JJ, Jensen BA, Mann KK, Ryu HY, Sherr DH: Peroxisome Proliferator-Activated Receptor g-Mediated NF-kB Activation and Apoptosis in Pre-B Cells. I Immunol 2002, 169:683|-684|.

51. Duyao MP, Buckler AJ, Sonenshein GE: Interaction of an NF-kBlike factor with a site upstream of the c-myc promoter. Proc. Natl. Acad. Sci. USA 1990, 87:4727.

52. Quadri S, Qadri A, Mann KL, Sherr DH: The bioflavonoid galangin blocks aryl hydrocarbon receptor (AhR) activation and polycyclic aromatic hydrocarbon-induced pre-B cell apoptosis. Molec. Pharmacol. 2000, 58:5।5-525.

53. Hennig B, Meerarani P, Slim R, Toborek M, Daugherty A, Silverstone $A E$, Robertson LW: Proinflammatory properties of coplanar PCBs: in vitro and in vivo evidence. Toxicol Appl Pharmacol 2002, 181:174-183

54. Yao Y, Hoffer A, Chang CY, Puga A: Dioxin activates HIV-I gene expression by an oxidative stress pathway requiring a functional cytochrome P450 CYPIAI enzyme. Environ Health Perspect 1995, 103:366-37I.

55. Dendorfer U, Oettgen P, Libermann TA: Multiple regulatory elements in the interleuken- 6 gene mediate induction by prostaglandins, cyclic AMP, and lipopolysaccharide. Mol Cell Biol 1994, I 4:4443-4454.

56. Baccam M, Woo SY, Vinson C, Bishop GA: CD40-mediated transcriptional regulation of the IL-6 gene in B lymphocytes: involvement of NF-kappa B, AP-I, and C/EBP. J Immunol 2003, 170:3099-3108

57. Zerbini LF, Wang Y, Cho JY, Libermann TA: Constitutive activation of nuclear factor kappaB p50/p65 and Fra-I and JunD is essential for deregulated interleukin 6 expression in prostate cancer. Cancer Res 2003, 63:2206-22I5. 
58. Henning B, Meerarani P, Slim R, Toberek M, Daugherty A, Silverstone $A E$, Robertson LW: Proinflammatory properties of coplanar PCBs: In vitro and in vivo evidence. Toxicol Appl Pharmacol 2002, | 8 I: |74- |83.

59. Puga A, Nebert DW, Carrier F: Dioxin induces expression of cfos and c-jun proto-oncogenes and a large increase in transcription factor AP-I. DNA and Cell Biol. I 992, I I :269-28I.

60. Puga A, Barnes SJ, Dalton TP, Chang C-y, Knudsen ES, Maier MA: Aromatic hydrocarbon receptor interaction with the retinoblastoma protein potentiates repression of E2F-dependent transcription and cell cycle arrest. J. Biol. Chem. 2000, 275:2943-2950.

61. Kang SM, Tran AC, Grilli M, Lenardo MJ: NF-kappa B subunit regulation in nontransformed CD4+ T lymphocytes. Science 1992, 256: |452-| 456 .

62. Duckett CS, Perkins ND, Kowalik TF, Schmid RM, Huang ES, A.S Baldwin Jr., Nabel G]: Dimerization of NF-kB2 with RelA(p65) regulates DNA binding, transcriptional activation, and inhibition by an IkB-a (MAD-3). Mole. Cell. Biol. I993, I3: I 3 I 5- I 322.

63. Gilmore TD, Koedood M, Piffat KA, White DW: Rel/NF-kB/IkB proteins and cancer. Oncogene 1996, I3:1367-1378.

64. Moos AB, Baecher-Steppan L, Kerkvliet NI: Acute inflammatory response to sheep red blood cells in mice treated with 2,3,7,8-tetrachlorodibenzo-p-dioxin: the role of proinflammatory cytokines, IL-I and TNF. Toxicol Appl Pharmacol I994, I 27:331-335.

65. Alsharif NZ, Hassoun E, Bagchi M, Lawson T, Stohs SJ: The effects of anti-TNF-alpha antibody and dexamethasone on TCDDinduced oxidative stress in mice. Pharmacology I994, 48: I 27-I 36.

66. Clark GC, Taylor MJ, Tritscher AM, Lucier GW: Tumor necrosis factor involvement in 2,3,7,8-tetrachlorodibenzo-p-dioxinmediated endotoxin hypersensitivity in C57BL/6J mice congenic at the Ah locus. Toxicol Appl Pharmacol I 99 I, I I I:422-43 I.

67. Ito T, Inouye K, Fujimaki H, Tohyama C, Nohara K: Mechanism of TCDD-induced suppression of antibody production: effect on $T$ cell-derived cytokine production in the primary immune reaction of mice. Toxicol Sci 2002, 70:46-54.

68. Zeytun A, McKallip RJ, Fisher M, Camacho I, Nagarkatti M, Nagarkatti PS: Analysis of 2,3,7,8-tetrachlorodibenzo-p-dioxin-induced gene expression profile in vivo using pathway-specific cDNA arrays. Toxicology 2002, I 78:24I-260.

69. Lai ZW, Hundeiker C, Gleichmann E, Esser C: Cytokine gene expression during ontogeny in murine thymus on activation of the aryl hydrocarbon receptor by 2,3,7,8-tetrachlorodibenzo-p-dioxin. Mol Pharmacol 1997, 52:30-37.

70. Warren TK, Mitchell KA, Lawrence BP: Exposure to 2,3,7,8-tetrachlorodibenzo-p-dioxin (TCDD) suppresses the humoral and cell-mediated immune responses to influenza $A$ virus without affecting cytolytic activity in the lung. Toxicol Sci 2000 , 56:1 14-123.

\section{Pre-publication history}

The pre-publication history for this paper can be accessed here:

http://www.biomedcentral.com/content/backmatter/ 1476-069x-2-16-b1.pdf

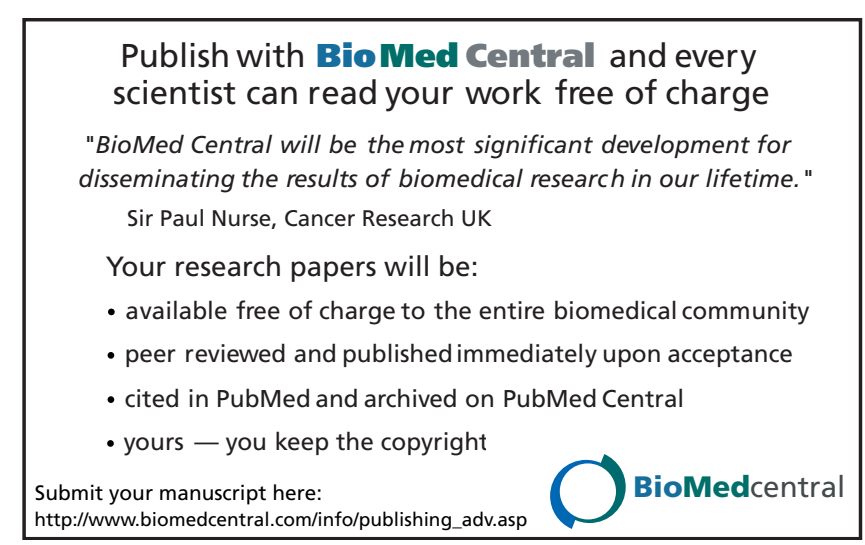

